\title{
ANALISIS FAKTOR FAKTOR YANG MEMPENGARUHI KUALITAS LAPORAN KEUANGAN PEMERINTAH DAERAH (Studi Kasus Pada Badan Pengelola Keuangan, Pendapatan Dan Aset Daerah Kabupaten Karo)
}

\author{
Sahala Purba \\ Universitas Methodist Indonesia \\ sahala824@gmail.com \\ Arison Nainggolan \\ Universitas Methodist Indonesia \\ arisonainggolan@gmail.com \\ Sella Yorenta Br Tarigan \\ Universitas Methodist Indonesia \\ sella.yorenta@gmail.com \\ Disubmit : 17 September 2021 \\ Direview : 3 Oktober 2021 \\ Diterima : 13 September 2021
}

\begin{abstract}
This study aims to determine and analyze the influence of human resource competence, utilization of information technology, internal control systems, and organizational commitment to local government financial reports. This type of research is causal associative research and uses primary data. The data collection method used is a questionnaire. The analytical method used in this research is descriptive analysis and multiple linear regression. This research was conducted at the Regional Finance, Revenue and Asset Management Agency of Karo Regency. Respondents in this study found 52 people. The results of this study indicate that the competence of human resources that affect the quality of reports on the use of information technology, internal control systems and organizational commitment does not affect the quality of the financial statements of the Karo Regency government.
\end{abstract}

Keywords: Human Resource Competence, Utilization of Information Technology, Internal Control Systems, and Quality of Local Government Financial Reports

\begin{abstract}
Abstrak
Penelitian ini bertujuan untuk mengetahui dan menganalisis pengaruh kompetensi sumber daya manusia, pemanfaatan teknologi informasi, sistem pengendalian intern dan komitmen organisasi terhadap kualitas laporan keuangan pemerintah daerah. Jenis penelitian ini adalah penelitian asosiatif yang bersifat kausal dan menggunakan data primer. Metode pengumpulan data yang digunakan adalah kuesioner. Metode analisis yang digunakan dalam penelitian ini adalah analisis deskriptif dan regresi linier berganda. Penelitian ini dilakukan pada Badan Pengelola Keuangan, Pendapatan dan Aset Daerah Kabupaten Karo. Responden dalam penelitian ini berjumlah 52 orang. Hasil penelitian ini menunjukkan bahwa kompetensi sumber daya manusia yang berpengaruh positip terhadap kualitas laporan keuangan sedangkan pemanfaatan teknologi informasi, sistem pengendalian internal dan komitmen organisasi tidak berpengaruh terhadap kualitas laporan keuangan pemerintahan pada Badan Pengelola Keuangan Pendapatan dan Aset Daerah Kabupaten Karo.
\end{abstract}


Kata Kunci : Kompetensi Sumber Daya Manusia, Pemanfaatan Teknologi Informasi, Sistem Pengendalian Internal, Komitmen Organisasi dan Kualitas Laporan Keuangan Pemerintah Daerah

\section{PENDAHULUAN}

Masih banyak kekurangan/kelemahan kualitas pelaporan keuangan pemerintah daerah yaitu relevansi laporan keuangan yang dilaporkan dan ketidakpatuhan. Laporan keuangan adalah laporan terstruktur mengenai posisi keuangan dan transaksi unit pelaporan keuangan. Peraturan Pemerintah Nomor 71 Tahun 2010 mengatur bahwa standar akuntansi negara merupakan pedoman dalam penyusunan dan penyajian laporan keuangan, baik bagi pemerintah pusat maupun daerah. Namun berdasarkan hasil audit BPK selaku auditor negara, pada semester I tahun 2017 BPK mengaudit 537 (99\%) laporan keuangan pemerintah daerah tahun 2016 dari 542 pemerintah daerah yang menghasilkan laporan keuangan tahun 2016. Sedangkan 5 daerah lainnya terlambat melaporkan sesuai dengan dana yang sah. Badan Pemeriksa Keuangan (BPK) juga mendeteksi 2.525 pelanggaran hukum yang mengakibatkan kerugian Rp 1,13 miliar dalam hasil pemeriksaan Laporan Keuangan Negara (LHP). (LKPD). Badan Pengawasan Tinggi (BPK RI) juga mengawasi beberapa laporan keuangan pemerintah pusat, khususnya Ketua BPK Agung Firman Sampurna, baik tentang Sistem Pengendalian Intern (SPI) maupun kepatuhan terhadap peraturan perundang-undangan yang dipantau.

\section{Tabel 1. Daftar Akun yang Disajikan Tidak Sesuai dengan SAP pada LKPD Kabupaten Karo Tahun 2019}

\begin{tabular}{clc}
\hline LKDP & Nama Akun & $\begin{array}{c}\text { Permasalahan } \\
\text { Terjadi Pada } \\
\text { Akun }\end{array}$ \\
\hline \multirow{2}{*}{$\begin{array}{c}\text { Kabupaten } \\
\text { Karo }\end{array}$} & Aset Lancar & $\mathrm{V}$ \\
\cline { 2 - 3 } & Aset Tetap & $\mathrm{V}$ \\
\cline { 2 - 3 } & Aset Lainnya \\
\cline { 2 - 3 } & Pendapatan \\
\cline { 2 - 3 } & Belanja Operasi \\
\cline { 2 - 3 } & Belanja Modal & $\mathrm{V}$ \\
\hline \multicolumn{2}{c}{ Akun Lainnya } & $\mathrm{V}$ \\
\hline
\end{tabular}

Sumber: https://www.bpk.go.id/ihps/2019/I

Pada tabel 1 dapat dilihat bahwa Laporan Keuangan Pemerintah Daerah Kabupaten Karo masih terdapat permasalahan pada beberapa akun yang disajikan tidak sesuai dengan standar akuntansi pemerintah daerah. Adapun tujuan penelitian ini adalah untuk mengetahui dan menganalisis pengaruh kompetensi sumber daya manusia, pemanfaatan teknologi, sistem pengendalian internal dan komitmen organisasi terhadap kualitas laporan keuangan pemerintah daerah pada BPKPAD Kabupaten Karo.

Menurut Ara, Herwanti dan Pituringsih (2016) Teori Stewardship memandang bahwa Pemerintah Daerah sebagai suatu lembaga negara yang dapat dipercaya untuk bertindak sesuai dengan kepentingan publik untuk melaksanakan tugas dan fungsinya dengan tepat, membuat pertanggungjawaban keuangan yang diamanahkan kepadanya, sehingga tujuan ekonomi, pelayanan publik maupun kesejahteraan masyarakat dapat tercapai secara maksimal. Sejalan dengan penjelasan tersebut di atas, Undang-undang No.32/2004 selain memberikan kewenangan otonomi kepada Pemerintah Daerah, juga mewajibkan tiap Kepala Daerah untuk memberikan

Laporan Penyelenggaraan Pemerintah Daerah (LPPD) kepada pemerintah pusat. Pasal 2 
peraturan pemerintah Nomor 3 tahun 2007 (PP No.3/2007) tentang laporan penyelenggaraan pemerintahan daerah kepada pemerintah, laporan keterangan pertanggungjawaban kepala daerah kepada dewan perwakilan rakyat daerah, dan informasi laporan penyelenggaraan pemerintahan daerah kepada masyarakat.

Sunyoto (2012) mendefinisikan kualitas sebagai "ukuran yang digunakan untuk menilai apakah suatu objek memiliki nilai guna atau, dengan kata lain, memiliki nilai guna seperti objek atau jasa. dianggap telah memiliki kualitas apabila berfungsi atau mempunyai nilai guna seperti yang diinginkan. Nordiawan (2007:294) mendefinisikan laporan keuangan tahunan sebagai "laporan terstruktur mengenai posisi keuangan dan transaksi yang dilakukan oleh perusahaan pelapor" Ada empat indikator untuk mengukur kualitas laporan keuangan yakni : 1) Dapat Dipahami. 2) Relevan. 3) Keandalan. 4) Dapat Dibandingkan

Kompetensi Sumber Daya Manusia didefinisikan menurut Mangkunegara (2012: 40): Kompetensi dalam kaitannya dengan pengetahuan, keterampilan dan sifat. Ada tiga indikator kompetensi sumber daya manusia, yakni : 1)Pengetahuan. 2) Keterampilan. 3) Sikap Adapun penelitian terdahulu yang menyatakan kompetensi sumber daya manusia yang berpengaruh terhadap kualitas laporan keuangan dilakukan oleh Armel (2017); Mulia (2018); Surastiani dan Handayani (2015).

Pemanfaatan teknologi informasi merupakan teknologi berbasis komputer untuk mengolah data menjadi informasi yang berkualitas dan berguna untuk pengambilan keputusan. Ada lima indikator pemanfaatan teknologi informasi, yakni : 1) Perangkat Keras Komputer. 2) Perangkat Lunak Komputer. 3) Jaringan dan Komunikasi. 4) Database. 5) Personalia Teknologi Informasi. Penelitian terdahulu yang menyatakan pemanfaatan teknologi informasi berpengaruh terhadap kualitas laporan keuangan dilakukan oleh Sari (2020); Chodijah dan Hidayah (2018)

Definisi pengendalian intern menurut (COSO, 2013) adalah "Pengendalian intern didefinisikan sebagai suatu proses yang dipengaruhi oleh dewan direksi, manajemen dan karyawan yang dirancang untuk memberikan jaminan yang menyakinkan bahwa tujuan organisasi akan dapat dicapai, ketaatan terhadap Undang-Undang yang berlaku". Ada lima indikator sistem pengendalian internal, yakni : 1) Lingkungan Pegendalian. 2) Penilaian Resiko. 3) Pengendalian. 4) Informasi dan Komunikasi. 5) Pemantauan dan Pengendalian Intern. Penelitian terdahulu yang menyatakan bahwa sistem pengendalian internal berpengaruh terhadap kualitas laporan keuangan dilakukan oleh Chodijah dan Hidayah (2018); Armel (2017) Putri AR dan Periansya (2019).

Khaerul Umam (2010:259) mendefinisikan bahwa "Komitmen organisasi memiliki arti penerimaan yang kuat dalam diri individu terdapat tujuan dan nilai-nilai organisasi, sehingga individu tersebut akan berkarya serta memiliki keinginan yang kuat untuk bertahan di organisasi" Ada tiga indikator Komitmen Organisasi, yakni : 1) Affektive commitment. 2) Continuance commitment. 3) Normative commitment. Penelitian terdahulu yang menyatakan bahwa komitmen organisasi berpengaruh terhadap kualitas laporan keuangan dilakukan oleh Widari dan Sutrisno (2017); Mutiana dan Diantimala dan Zuraida (2017) dan Eveline (2016) Adapun hipotesis penelitian ini adalah

$\mathrm{H}_{1}$ : Kompetensi Sumber Daya Manusia berpengaruh positif terhadap Kualitas Laporan Keuangan

$\mathrm{H}_{2}$ : Pemanfaatan Teknologi berpengaruh positif terhadap Kualitas Laporan Keuangan

$\mathrm{H}_{3}$ : Sistem Pengendalian Internal berpengaruh positif terhadap Kualitas Laporan Keuangan

$\mathrm{H}_{4}$ : Komitmen Organisasi Berpengaruh Positif terhadap Kualitas Laporan Keuangan 


\section{METODE PENELITIAN}

Jenis penelitian ini adalah penelitian kuantitatif dan menggunakan data primer. Objek/lokasi penyidikan dilakukan di Badan Pengelolaan Keuangan, Pendapatan, dan Aset Daerah Kabupaten Karo. Populasi dalam penelitian ini adalah seluruh pegawai BPKPAD Kab Karo. Sampel untuk penelitian ini diyakini terdiri dari 59 responden. Teknik pengambilan sampel dalam penelitian ini menggunakan sensus. Metode pengumpulan data dilakukan melalui angket wawancara dan observasi. Metode analisis data yang digunakan dalam penelitian ini adalah analisis statistik deskriptif dan analisis linier berganda dengan bantuan program SPSS Vers 23.

Tabel 2. Definisi Operasional Variabel

\begin{tabular}{lllll}
\hline Variabel & Definisi operasional & Indikator & & $\begin{array}{l}\text { Skala } \\
\text { Pengukuran }\end{array}$ \\
\hline Variabel Dependen (Terikat ) & & & \\
\hline Kualitas & Peraturan Pemerintah No. 71 & Menurut & Soermaso & Interval \\
Laporan & Tahun 2010 menyatakan bahwa & $(2004: 21)$ : & & \\
Keuangan & "Laporan keuangan merupakan & 1. Relevan & \\
(Y) & laporan yang terstruktur mengenai & 2. Andal & \\
& posisi keuangan dan transaksi- & 3. Dapat dibandingkan & \\
& transaksi yang dilakukan oleh entitas & 4. Dapat dipahami & \\
& pelaporan" & & & \\
\end{tabular}

\begin{tabular}{|c|c|c|c|}
\hline \multicolumn{4}{|c|}{ Variabel Independen (Bebas) } \\
\hline $\begin{array}{l}\text { Kompetensi } \\
\text { Sumber Daya } \\
\text { Manusia }\left(\mathrm{X}_{1}\right)\end{array}$ & $\begin{array}{l}\text { Mangkunegara }(2012: 40) \\
\text { Kemampuan yang dimiliki seseorang } \\
\text { yang berhubungan dengan } \\
\text { pengetahuan, keterampilan, dan } \\
\text { karakteristik kepribadian yang } \\
\text { mempengaruhi secara langsung } \\
\text { terhadap kinerjanya }\end{array}$ & $\begin{array}{l}\text { Menurut Sutrisno } \\
(2009: 204) \\
\text { 1. Pengetahuan } \\
\text { 2. Keterampilan } \\
\text { 3. Perilaku }\end{array}$ & Interval \\
\hline $\begin{array}{l}\text { Pemanfaatan } \\
\text { Teknologi } \\
\text { Informasi } \\
\left(\mathrm{X}_{2}\right)\end{array}$ & $\begin{array}{l}\text { Mulyadi (2014:21) menyatakan } \\
\text { "Teknologi informasi adalah studi } \\
\text { penggunaan peralatan elektronika, } \\
\text { terutama komputer, untuk } \\
\text { menyimpan, menganalisis, dan } \\
\text { mendistribusikan informasi apa saja, } \\
\text { termasuk kata-kata, bilangan dan } \\
\text { gambar". }\end{array}$ & $\begin{array}{l}\text { Menurut Suyanto } \\
(2005: 11) \text { : } \\
\text { 1. Perangkat Keras } \\
\text { 2. Perangkat Lunak } \\
\text { Komputer } \\
\text { 3. Jaringan dan } \\
\text { Komunikasi } \\
\text { 4. Database } \\
\text { 5. Personalia } \\
\text { Teknologi Informasi }\end{array}$ & Interval \\
\hline $\begin{array}{l}\text { Sistem } \\
\text { Pengendalian } \\
\text { Internal }\left(\mathrm{X}_{3}\right)\end{array}$ & $\begin{array}{l}\text { Peraturan Pemerintah Nomor } 60 \\
\text { Tahun } 2008 \text { menyatakan bahwa SPI } \\
\text { ialah proses yang integral pada } \\
\text { tindakan dan kegiatan yang } \\
\text { dilakukan secara terus menerus oleh } \\
\text { pimpinan dan seluruh pegawai untuk } \\
\text { memberikan keyakinan memadai } \\
\text { atas tercapainya tujuan organisasi } \\
\text { melalui kegiatan yang efektif dan } \\
\text { efesien, keandalan pelaporan } \\
\text { keuangan, pengamanan aset negara }\end{array}$ & $\begin{array}{l}\text { 1. Menurut PP No. } \\
60 \text { Tahun } 2008 \text { : } \\
\text { 2. Lingkungan } \\
\text { pengendalian } \\
\text { 3. Penilaian resiko } \\
\text { 4. Pengendalian } \\
\text { 5. Informasi dan } \\
\text { komuikasi } \\
\text { 6. Pemantauan dan } \\
\text { pengendalian } \\
\text { intern }\end{array}$ & Interval \\
\hline
\end{tabular}




\begin{tabular}{llll}
\hline & dan ketaatan terhadap peraturan & & \\
& perundang- undangan & & \\
\hline Komitmen & Khaerul Umam (2010:259) & Menurut Allen & Interval \\
Organisasi & mendefinisikan bahwa "Komitmen & dan Meyer (2011) & \\
$\left(\mathrm{X}_{4}\right)$ & Organisasi memiliki arti penerimaan & 1. Affektive & \\
& yang kuat dalam diri individu & commitment & \\
& terdapat tujuan dan nilai-nilai & 2. Continuance \\
& organisasi, sehingga individu & commitment \\
& tersebut akan berkarya serta memiliki & 3. Normative \\
& keinginan yang kuat untuk bertahan & commitment \\
& di organisasi." & & \\
\hline
\end{tabular}

Sumber: dari berbagai jurnal, 2021

\section{HASIL DAN PEMBAHASAN}

Responden dalam penelitian ini didomisili oleh jenis kelamin perempuan 38 orang atau $64,4 \%$ dan sisanya sebanyak 21 orang atau 35,6\% berjenis kelamin laki-laki. Responden dalam penelitian ini didomisi oleh lulusan Sarjana 29 orang atau 49,1\%, lulusan SMA/Sederajat 12 orang atau 20,3 \%, lulusan Diploma 11 Orang atau 18,7 \%, lulusan Magister 6 orang atau 10,2 $\%$ dan lulusan SMP 1 orang atau $1,7 \%$.

\section{Uji kualitas instrumen}

Uji validitas digunakan untuk mengukur valid atau tidaknya suatu angket. Jika nilai tabel korelasi total item rhitung $>\mathrm{r}$ dan nilainya positif, maka item penelitian untuk setiap variabel diasumsikan menang (Ghozali, 2016). Semua nilai $r$ hitung untuk masing-masing pertanyaan tentang kompetensi sumber daya manusia, pemanfaatan teknologi informasi, sistem pengendalian internal, komitmen organisasi dan kualitas laporan keuangan lebih besar dari $r$ tabel $(0,256)$. Suatu kuesioner dikatakan reliabel jika tanggapan seseorang terhadap pernyataan tersebut konsisten atau tidak stabil dari waktu ke waktu. Suatu konstruksi suatu variabel menjadi reliabel jika nilai cronbach's alpha >0,60 (Ghozali, 2016).

\section{Uji Hipotesis}

Uji t

\begin{tabular}{lccccc}
\multicolumn{7}{c}{ Tabel 3. Uji t } \\
Coefficients
\end{tabular}

Sumber: Hasil Olahan SPSS Versi 23, 2021

Berdasarkan hasil uji-t di atas, pengaruh variabel terikat dapat dijelaskan sebagai berikut: 
1. Nilai jumlah kualifikasi sumber daya manusia adalah $2.073>$ t Tabel 2.002 dan nilai signifikansinya adalah $0,043<0,05$. Dengan demikian dapat disimpulkan dari hasil yang diperoleh bahwa kompetensi sumber daya manusia berpengaruh positif.

2. Nilai $t$ hitung dengan nilai $t$ tabel yaitu dari output SPSS adalah $t$ hitung variabel penggunaan teknologi informasi $-0,178<\mathrm{t}$ tabel 2,002 dan nilai signifikansi 0,859 $>0,05$. Nilai ini menunjukkan bahwa hipotesis kedua penggunaan teknologi informasi tidak berpengaruh

3. Nilai counter $t$ dengan $t$ tabel berasal dari output SPSS, nilai counter $t$ variabel sistem pengendalian intern sebesar -2.093 < nilai t tabel sebesar 2.002 dan nilai signifikansi sebesar $0,041<0,05$. Nilai ini juga menunjukkan bahwa asumsi sistem pengendalian intern tidak berpengaruh

4. Nilai $\mathrm{t}$ hitung variabel keterikatan organisasi adalah $-1.169<\mathrm{t}$-tabel 2,002 dan nilai signifikansi 0,248>0,05. Nilai tersebut menunjukkan bahwa asumsi keempat tidak berpengaruh terhadap kualitas laporan keuangan.

\section{Uji Statistika F}

\begin{tabular}{llrrrrr}
\multicolumn{7}{c}{ Tabel 4. Uji F } \\
ANOVA
\end{tabular}

Sumber: Hasil Olahan SPSS Versi 23, 2021

Karena $\mathrm{F}$ hitung jauh lebih besar dari $\mathrm{F}$ tabel dan nilai probabilitas (Sig) lebih kecil dari 0,05 maka model regresi dapat digunakan untuk memprediksi bahwa secara bersama-sama kualitas laporan keuangan pemerintah daerah dapat dipengaruhi oleh variabel kompetensi sumber daya manusia, pemanfaatan teknologi informasi, sistem pengendalian internal dan komitmen organisasi.

\section{Uji Koefisien Determinasi $\left(\mathbf{R}^{2}\right)$}

Tabel 5. Uji Koefisien Determinasi

Model Summary

\begin{tabular}{lrrrr} 
Model & R & R Square & $\begin{array}{c}\text { Adjusted R } \\
\text { Square }\end{array}$ & \multicolumn{2}{c}{ Std. Error of the Estimate } \\
\hline 1 & $.440^{\mathrm{a}}$ & .194 & .134 & 1.906 \\
\hline
\end{tabular}

Sumber: Hasil Olahan SPSS Versi 23, 2021

Berdasarkan hasil uji koefisen determinasi $\left(\mathrm{R}^{2}\right)$ yang ditunjukkan pada tabel, diperoleh nilai adjusted $R$-square sebesar 0,134 atau 13,4 \%. Hal ini menunjukkan bahwa sebesar 13,4 \% kulitas laporan keuangan pada BPKPAD Kab. Karo dipengaruhi oleh kompetensi sumber daya manusia, pemanfaatan teknologi informasi, sistem pengendalian internal dan komitmen organisasi, sedangkan sisanya sebesar $86,6 \%$ dipengaruhi oleh variabel-variabel lain yang tidak dimasukkan dalam penelitian ini. 


\section{Pembahasan}

\section{Pengaruh Kompetensi Sumber Daya Manusia terhadap Kualitas Laporan Keuangan Pemerintah Daerah}

Hasil penelitian ini mendukung hipotesis 1 yang menyatakan bahwa variabel kompetensi sumber daya manusia berpengaruh positif terhadap kualitas laporan keuangan pemerintah daerah bisa dilihat pada tabel uji t sehingga hipotesis ini dapat diterima

Kompetensi sumber daya manusia yang dilaksanakan dengan baik, maka kualitas laporan keuangan pemerintah akan meningkat, sehingga laporan keuangan yang baik dapat memenuhi karakteristik kualitatif laporan keuangan. sumber daya manusia yang memiliki kompetensi akan dapat menyelesaikan pekerjaaannya secara efesien dan efektif. Hasil penelitian ini didukung dengan penelitian terdahulu yang dilakukan oleh Rohmah dan Askandar dan Sari (2020), Taman(2017) dan Armel (2017).

\section{Pengaruh Pemanfaatan Teknologi Informasi terhadap Kualitas Laporan Keuangan Pemerintah Daerah}

Hipotesis kedua yang diajukan Pemanfaatan Teknologi Informasi berpengaruh positif terhadap Kualitas Laporan Keuangan. Berdasarkan hasil uji t dimana nilai signifikannya diatas 0,05, dengan demikian hipotesis kedua ditolak yang artinya pemanfaatan teknologi informasi tidak berpengaruh terhadap kualitas laporan keuangan.

Walaupun teknologi informasi semakin canggih tetapi bila tidak dibarengi dengan pemahaman, penguasaan dan diperlukan pelatihan dan proses kerja yang baik, maka teknologi informasi tidak dapat dimanfaatkan dengan tepat. Sehingga kualitas laporan yang dihasikan belum sepenuhnya menghasilkan kualitas laporan keuangan yang baik.Hasil ini didukung dengan penelitian yang dilakukan oleh Surastiani dan Handayani (2015), Setyowati dan Isthika dan Pratiwi (2016)

\section{Pengaruh Sistem Pengendalian Internal terhadap Kualitas Laporan Keuangan Pemerintah Daerah}

Hipotesis ketiga yang diajukan sistem pengendalian internal berpengaruh positif terhadap kualitas laporan keuangan. Dari hasil uji t dapat dilihat bahwa sistem pengendalian internal tidak berpengaruh signifikan terhadap kualitas laporan keuangan sehingga hipotesisnya ditolak.

Sistem pengendalian intern menjadi salah satu faktor yang mempengaruhi kualitas laporan keuangan pemerintah daerah sejalan dengan temuan BPK atas lemahnya sistem pengendalian intern yang mengakibatkan kebocoran dan ketidakpatuhan terhadap peraturan perundangundangan sehingga BPK memberi opini Tidak Wajar (TW) bahkan Tidak Memberikan Pendapat (TMP) atas sebahagian besar LKPD di Indonesia. Hasil penelitian ini didukung oleh peneliti terdahulu yang dilakukan oleh dan Ardianto (2019) dan Yensi (2014) yang menyatakan bahwa sistem pengendalian internal tidak berpengaruh terhadap kualitas laporan keuangan pemerintah.

\section{Pengaruh Komitmen Organisasi terhadap kualitas Laporan Keuangan Pemerintah Daerah}

Hipotesis keempat yang diajukan menyatakan bahwa Komitmen Organisasi berpengaruh positif terhadap kualitas laporan keuangan. Dari hasil tabel uji t diatas dapat dilihat bahwa komitmen organisasi tidak berpengaruh terhadap kualitas laporan keuangan pemerintahan daerah, sehingga hipotesisnya ditolak.

Hal ini disebabkan karena masih belum semuanya memiliki perasaan berat untuk meninggalkan organisasi dikarenakan kebutuhan untuk bertahan dengan pertimbangan biaya apabila meninggalkan organisasi, berusaha diatas batas normal untuk mensukseskan organsisasi dan tidak semua pegawai yang menjadikan masalah organisasi sebagai masalah 
pegawai dan tidak semua pegawai memiliki ikatan emosional dengan organisasi atau instansi tempat pegawai bekerja. Hasil penelitian ini didukung oleh penelitian terdahulu Shintami Oktavia dan Sri Rahayu (2019).

\section{SIMPULAN}

Dari hasil analisis data dan pembahasan yang telah dilakukan, maka dapat diambil kesimpulan bahwa Kompetensi Sumber Daya Manusia berpengaruh positif terhadap kualitas laporan keuangan pemerintah pada Badan Pengelola Keuangan, Pendapatan Asli Daerah dan Aset Daerah Kabupaten Karo. Pemanfaatan Teknologi Informasi tidak berpengaruh terhadap Kualitas Laporan Keuangan Pemerintah pada Badan Pengelola Keuangan Daerah, Pendapatan dan Aset Kabupaten Karo. Sistem Pengendalian Intern tidak berpengaruh terhadap Kualitas Laporan Keuangan Pemerintah pada Badan Pengelola Keuangan Daerah, Pendapatan dan Aset Kabupaten Karo. Komitmen Organisasi tidak berpengaruh terhadap Kualitas Laporan Keuangan Pemerintah pada Badan Pengelola Keuangan, Pendapatan Asli Daerah dan Aset Daerah Kabupaten Karo.

Berdasarkan kesimpulan terdapat beberapa saran Bagi peneliti selanjutnya dalam melakukan analisis faktor-faktor yang mempengaruhi kualitas laporan keuangan di masa mendatang agar dapat memperluas atau menambah sample penelitian seperti di luar Kabupaten Karo atau menambah periode pengamatan. Selanjutnya saran peneliti selanjutnya untuk variabel independen baru yaitu: 1) peran audit internal. 2) Penerapan standar akuntansi pemerintah. 3) pengawasan keuangan daerah. Bagi BPKPAD Kabupaten Karo yang menjadi subjek dalam penelitian ini agar lebih memperhatikan aspek kompetensi sumber daya manusia, pemanfaatan teknologi informasi, sistem pengendalian internal dan komitmen organisasi.

\section{DAFTAR PUSTAKA}

Allen dan Meyer, 2011, Organizational Commitment in Higher Education. Jackson State University:Mississippi.

Ara, Herwanti dan Pituringsih. 2016. Pengaruh Karakteristik Pemda Dan Temuan Audit BPK Terhadap Kinerja Pemda Kabupaten Di Pulau Sumba., JAFFA, Vol. 04 No. 1 April 2016. Hal 1-17

Ardianto \& Eforis. 2019. "Pengaruh Penerapan Standar Akuntansi Pemerintah, Pemanfaatan Teknologi Informasi, Kompetensi Sumber Daya Manusia, Penerapan Sistem Pengendalian Intern Pemerintah, Dan Sistem Akuntansi Keuangan Daerah Terhadap Kualitas Laporan Keuangan Pemerintah Daerah." Jurnal Bina Akuntansi Vol.6 No.1 95 $-136$.

Committee of Sponsoring Organization (COSO) of The Treadway Commission. 2013. Internal Control - Integrated Framework: Executive Summary. COSO. Mei 2013.

Erlina, Sri Mulyani. 2007. Metodologi Penelitian Bisnis : Untuk Akuntansi dan Manajemen, Cetakan Pertama USU Press, Medan.

Ghozali. 2016. Aplikasi Analisis Multivariate dengan Program SPSS. Badan Penerbit Universitas Diponegoro.

Keputusan Kepala Badan Kepegawaian Negara RI No. 46A Tahun 2003 tentang Pedoman Penyusunan Standar Kompetensi Jabatan Struktural Pegawai Negeri Sipil.

Khaerul Umam, 2010. Perilaku Organisasi. Cetakan 1. CV Pustaka Setia. Bandung Mangkunegara (2012). Manajemen Sumber Daya Manusia. Bandung: PT. Remaja Rosdakarya. Mulyadi. 2014. Sistem Akuntansi. Cetakan Keempat. Jakarta : Salemba Empat.

Nordiawan., et.al. 2007. Akuntansi Pemerintahan, Jakarta : Salemba Empat 